Law \& Economics Working Papers

Law \& Economics Working Papers Archive:

2003-2009

University of Michigan Law School

Year 2004

\title{
An Ex-Ante View of the Battle of the \\ Forms: Inducing Parties to Draft \\ Reasonable Terms
}

\author{
Omri Ben-Shahar \\ University of Michigan Law School, omri@uchicago.edu
}

This paper is posted at University of Michigan Law School Scholarship Repository.

http://repository.law.umich.edu/law_econ_archive/art32 


\title{
UNIVERSITY OF MICHIGAN
}

JOHn M. OLin CENTER FOR LAW \& ECONOMICS

\section{AN EX-ANTE VIEW OF THE BATTLE OF THE F ORMS: INDUCING PARTIES TO DRAFT REASONABLE TERMS}

\author{
OMRI BEN-SHAHAR
}

PAPER \#04-018

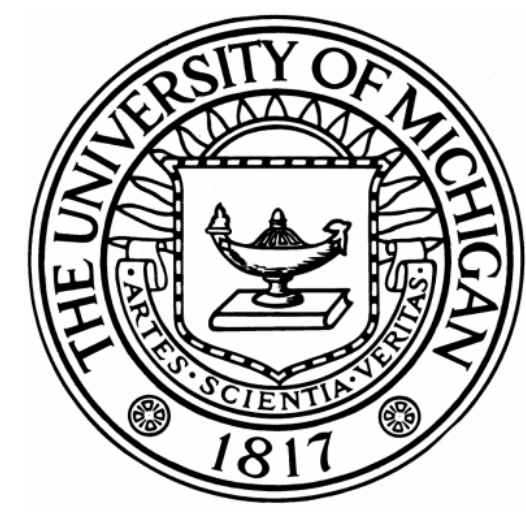

THIS PAPER CAN BE DOWNLOADED WITHOUT CHARGE AT:

Michigan John M. OLin Website

HTTP://WWW.LAW.UMICH.EDU/CENTERSANDPROGRAMS/OLIN/PAPERS.HTM 


\title{
AN EX-ANTE VIEW OF THE BATTLE OF THE FORMS: INDUCING PARTIES TO DRAFT REASONABLE TERMS
}

\author{
Omri Ben-Shahar*
}

\begin{abstract}
$\underline{\text { Abstract }}$
This paper focuses on one type of ex-ante effect of the battle of the forms: the incentive to draft reasonable boilerplate terms. It argues that the experience with the battle-of-the-forms rule under the CISG reinforces what we already know, that existing legal solutions do not provide any incentive for the parties to draft reasonable forms. The paper suggests that the goal of inducing parties to draft reasonable terms can be significantly promoted by a third rule, a variant of the "best-shot" rule proposed by Victor Goldberg. Under the version labeled the "reasonableshot" rule, the court would resolve the battle of the forms by choosing the form that contains the more efficient terms. The paper proposes some guidelines how the "reasonable shot" could be identified by the court, and argues that there are good reasons to expect that this regime would give parties the incentive to draft reasonable terms. In fact, it is plausible that under this rule the parties' forms would converge and the battle of the forms would cease to exist.
\end{abstract}

\footnotetext{
* Professor of Law and Economics, University of Michigan Law School, Ann Arbor, MI 48109 (omri@umich.edu). This paper is prepared for the Conference on Commercial Law Theory and the CISG, Florence, Italy, October 2004. I am grateful to Gillian Hadfield, Roy Kreitner, Alberto Monti, Ariel Porat, Ted St. Antoine, Jim White and participants at the conference on Commercial Law Theory and the CISG in Florence, Italy, for helpful comments and to Ann McCune and James Miltner for valuable research assistance. Financial support from the John M. Olin Center for Law and Economics at the University of Michigan is gratefully acknowledged.
} 


\section{INTRODUCTION}

The "Battle of the Forms", one of the oldest problems in modern contract law, is widely recognized to be among the most difficult problems for contracts doctrine to resolve. In the U.S., the rules governing the battle of the forms have been famously labeled "chaos". " Commentators, judges, and legislators, continue to view the battle of the forms as a problem that has not lent itself to a conceptually satisfactory solution. ${ }^{2}$

Improving the law's solution to the battle of the forms is a task that is very much on the agenda of current contract law. The Section governing the battle of the forms in the Uniform Commercial Code ("the Code"), 2207, is perhaps the most litigated section in contract law, ${ }^{3}$ and a landmark battlefront during the amendment proceeding of Article 2. Similarly, the enactment of Section 19 of CISG, whic h governs the battle of the forms in international sales of goods, involved a similar prolonged debate, bringing to the fore the different conceptual solutions to this everyday commercial problem. ${ }^{5}$

A striking feature of the debates over the battle of the forms is how little it has been influenced by the economic analysis of contract law. Apart from a few interesting exceptions, the vast literature on the battle of the forms - and I'm not referring to the strictly doctrinal inquiries-takes a

\footnotetext{
${ }^{1}$ John Murray labeled the law on the battle of the forms "chaos" and concluded recently that the over time it has only exacerbated. See Murray, The Chaos of the Battle of the Forms: Solutions, 39 Vand. L. Rev. 1307 (1986) (hereinafter, "Murray, Chaos I) and Murray, The Definitive "Battle of the Forms": Chaos Revisited, 20 J. L. \& Comm. 1, 47 (2000) (hereinafter, "Murray, Chaos II);

2 "Legal science has not yet found a satisfactory way to decide what the parties have agreed when they have consummated a transaction on the basis of the routing exchange of inconsistent terms." See JOHN HONNOLD, UNIFORM LAW OF INTERNATIONAL SALES UNDER THE 1980 UNITED NATIONS CONVENTION 228 (2d Ed. 19 ).

${ }^{3}$ WHITE \& SUMMERS, 1 UNIFORM COMMERCIAL CODE ( $4^{\text {th }}$ Ed. 1995); Murray, Chaos II, supra note 1, at 4 (Section 2-207 "belies what has become the most complex and controversial section of the entire Uniform Commercial Code")

${ }^{4}$ James J. White, Contracting Under Amended 2-207, 2004 Wisc. L.Rev. (forthcoming).

${ }^{5}$ The United Nations Convention on Contracts for the International Sale of Goods, Apr. 11 1980, 52 Fed. Reg. 40, 6264 (1987), 19 I.L.M 668 (1980) [hereinafter CISG], art 19. For an account of the legislative debates over Section 19, see Christine Moccia, The United Nations Convention on Contracts for the International Sale of Goods and the “Battle of the Forms,” 13 Fordham Int'1 L. J. 649 (1989).
} 
distinctly ex-post perspective, searching for solutions that would best identify the bargain-in-fact of the parties, eliminate undue hardship and surprise, avoid arbitrary biases, reduce litigation costs, and provide a fair compromise. ${ }^{6}$ While some of theses perspectives are "economic" in the sense that they address efficiency issues (e.g., how efficient are the terms that courts can supply ${ }^{7}$ ), they primarily take an ex-post efficiency view. Their scope is: given the divergence between the parties' forms, how to minimize social waste.

In most other areas of contract law, the main added value of economic analysis is the understanding of how legal rules shape the incentives to draft contracts and to behave prior to a dispute, that is, the ex-ante effects. Remedies, for example, are viewed as incentives to invest and perform contracts; ${ }^{8}$ Gap-filler are viewed as incentives to economize on drafting and share information prior to performance; ${ }^{9}$ and the rules governing offer-and-acceptance are viewed as incentives to communicate and $t \mathrm{invest}$ in the negotiations. ${ }^{10}$ With few exceptions, the literature on the battle of the forms did not accord the ex-ante effects equal attention.

The analysis in this paper seeks to contribute to the study of one type of incentive that may be influenced by the battle of the forms rules: the incentive to draft terms in a way that is more or less self-serving to the drafter. True, this is still not the type of primary ex-ante behavior that economists are most interested in explaining-e.g., quality of products and their price. But even an understanding of how primary economic variables are affected by the rule would be incomplete without an inquiry as to how the secondary terms - those over which battles of the forms are mounted-are designed.

\footnotetext{
${ }^{6}$ See, e.g., Ostas and Leete, Economic Analysis of Law as a Guide to Post-Communiste Legal Reforms: The Case of Hungarian Contract Law, 32 Amer. Bus. L. J. 355, 381-82 (1995).

${ }^{7}$ See, e.g., Note, Demilitarizing the Battle of the Forms: A Peace Proposal, 1990

Colum. Bus. L. Rev. 553, 570.

${ }^{8}$ See, e.g., Edlin, Breach Remedies, in 1 The New Palgrave Dictionary of Economics and the Law 174 (P. Newman, Ed., 1998).

${ }^{9}$ E.g., Goetz and Scott, The Limits of Expanded Choice: an Analysis of the Interactions Between Express and Implied Contract Terms, 75 Calif. L. Rev. 261 (1985).

10 See, e.g., Avery Katz, The Strategic Structure of Offer and Acceptance: Game

Theory and the Law of Contract Formation, 89 Mich. L. Rev. 215 (1990).
} 
The analysis of the $e x$-ante effects begins by looking at the time period in which the forms - having been drafted earlier-are exchanged between the parties. The argument here is not new: both theoretically and practically, there is little reason to expect that the battle of the form rules would do much to affect the incentive to read the other party's terms. In fact, some new support for this view comes from observations regarding the practices under the CISG. The paper identifies an interesting ambiguity regarding the resolution of the battle of the forms under the CISG, which is consistent only with the premise that form terms are utterly disregarded at the contracting stage. Thus, the paper joins previous voices that argued that legal policy should focus on the second type of incentive - the incentives to draft reasonable terms.

Previous literature recognized that battle of the forms rules could shape the incentives to draft form terms. In an insightful article, Baird and Weisberg argued that the common law's formalistic "last-shot" rule provides superior incentives for the parties to draft moderate provisions that are mutually beneficial. ${ }^{11}$ Expecting the some of their counterparts would read and reject one-sided terms, parties would draft forms that are acceptable to such "readers." In Section III of the paper, after explaining this argument, I will join others before me in doubting whether this effect is robust. I will argue that neither of the two standard solutionsthe "last-shot" rule of common law and the "knockout" rule of sales law-provides any meaningful incentive to write moderate terms.

Because the incentives to draft moderate terms is the focus of this paper, a natural question to ask is whether a different rule might generate better incentives than existing solutions. Accordingly, the paper will analyze in detail a third and less familiar rule that has the potential to create more powerful ex-ante incentives to draft reasonable terms. This rule, the "reasonable shot rule" - a variant of which was previously identified in an original paper by Victor Goldberg and labeled by him the "best-shot" rule $^{12}$ - would require the court to enforce the form containing the more reasonable terms. The court cannot concoct its own reasonable compromise; nor is it obligated to choose the form that was

\footnotetext{
11 Douglas Baird and Robert Weisberg, Rules, Standards, and the Battle of the Forms: A Reassessment of $\$ 2-207,68$ Va. L. Rev. 1217, 1252-57 (1982).

${ }^{12}$ Victor Goldberg, The Battle of the Forms: Fairness, Efficiency, and the Best-Shot Rule, 76. Ore. L. Rev. 155 (1997) (proposing that courts would choose the fairer of the two nonconforming forms.)
} 
presumptively "accepted." Instead, the court must choose one of the two forms, that which is more reasonable. This approach resembles the wellknown finaloffer arbitration procedure (FOA), often used in labor bargaining to determine salaries, ${ }^{13}$ in which each side submits its position and the arbitrator must choose one of the two positions which she considers to be closer to the underlying "correct" or ideal resolution. This procedure has a well-documented effect of moderating the parties' demands and inducing settlements, and similar dynamics can arise under the reasonable-shot rule, providing a powerful inducement for parties to draft their forms ex-ante in a more reasonable manner. In fact-this argument will be developed below-the incentives to moderate could be powerful enough for the parties' forms to converge, and "in equilibrium" the battle of the forms would cease to exist.

However, for the reasonable-shot rule to succeed in inducing parties to change their drafting habits and to write reasonable terms, courts must be able to apply this standard and identify the more reasonable form in a predictable fashion. Accordingly, the analysis in the paper explores various criteria that were not explored before, which may be utilized in implementing this standard. The objective of the analysis here is to examine whether courts are institutionally capable of identifying the more reasonable terms.

The paper is structured as follows. Section II sets up the different solutions to the battle of the forms. The two familiar solutions-the "last-shot" rule and the "knockout" rule-are presented briefly; the less familiar solution of the "reasonable shot" rule is presented in more detail. Section III then discusses the ex ante effects of these three rules, with particular emphasis on contract drafting. Section IV concludes.

\section{THE BATTLE OF THE FORMS : SOLUTIONS}

\footnotetext{
${ }^{13}$ A notable application of FOA is baseball's salary arbitration. It is well documented that the application of FOA causes parties' positions to converge, increasing the incidence of settlement, and rendering the final outcome more tolerable even for the losing side. For accounts of baseball's FOA experience, see Roger Abrams, THE MONEY PITCH : BASEBALl FREE AGENCY AND SALARY ARBITRATION (1990); John L. Fizel, Play Ball: Baseball Arbitration After 20 Years, 20 Disp. Resol. J. 42 (1994).
} 


\section{A. The Problem}

The problem known as the battle of the forms is common. Businessmen discuss a transaction and agree-orally or through written communications-on the performance terms of the deal, e.g., price, quantity and description of goods, payment terms, perhaps one or two other provisions. In the course of exchanging these communications, or in the course of formally memorializing the terms orally agreed upon over the phone, the parties exchange forms that contain additional "lawyers' terms" concerning non-performance contingencies, usually governing the scope of warranty, limitations on remedies, forum selection, and the like. These forms, each of which was pre-drafted by legal council in a manner favorable to the party using it, rarely agree. The seller's form, for example, would usually include a boilerplate disclaimer of warranties and a significant limitation on damages, whereas the buyer's form would either require some expanded warranty or entitle the buyer to a generous measure of consequential damages.

When the battle of the forms is discovered (and adjudicated) prior to performance or to any type of conduct that indicates the existence of a contract, the question is whether the communications formed a contract. Here, the old common law "mirror-image" rule, which established that a contract never formed, ${ }^{14}$ was reformed under the Uniform Commercial Code's ("the Code") §2-207(1). The Code adopted the view that a response can manifest acceptance even if it contains terms that are not matching. ${ }^{15}$ Yet this type of battle of the forms-a pre-performance dispute over the existence of a contract-is not very likely to reach courts. It is usually a wiser business strategy for a party to seek other contracts than to engage in a lawsuit over hypothetical losses suffered from the breakdown of a relationship that never actually budded.

The far more common battle of the forms dispute occurs after parties have performed the contract, or have otherwise engaged in conduct that indicates the existence of a contract. Here, the question is not whether a contract exists (it obviously does), but rather what are the contract's terms. Usually the parties have exchanged at least two forms-a purchase order by the buyer followed by an acknowledgment or an

${ }^{14}$ See Poel v. Brunswick, 110 N.E. 619 (1915) for the strict application of this result, but compare to A.B.Small Co. v. American Sugar Ref. Co., 267 U.S. 233 (1925), which adopts a more lenient approach. This rule was adopted by the CISG art. 19(1).

${ }^{15}$ White \& Summers, supra note 3 , at 8. 
invoice from the seller (or vice versa: a price quote from the seller followed by a purchase order) — only to realize, after delivery and payment have been made, that the forms differ with respect to a contingent term that, as it happens, turned out to matter a lot. Determining the content of the contract is the problem that the law has to resolve.

\section{B. The "Last-Shot" Rule}

Under the traditional common law approach known as the "last shot" rule, adopted by the CISG, the mirror-image rule implies that each form, by virtue of having some different terms relative to the previous form, cannot be deemed an acceptance and thus must be regarded as a "counter-offer." A counter-offer is treated in most legal systems as a "bundle" of two legal effects: a rejection of the previous offer and the making of a new outstanding offer. ${ }^{16}$ Thus, since each form rejects its predecessor and since rejection terminates the offer, the only form that is not affirmatively rejected and can potentially be accepted is the last form in the sequence, and its terms govern.

This solution, while formally preserving the offer/acceptance module as the only template of contract formation, is far from satisfactory. For one, contract law is usually stricter in recognizing silence as acceptance of terms. ${ }^{17}$ Nothing in the conduct of the parties indicates that the last shot, or any other shot, includes the acceptable of boilerplate terms. Indeed, the symmetric passivity of each party regarding the other party's form may be equally consistent with the opposite construction, namely a "first-shot" rule. ${ }^{18}$ Of course, both the first-shot and the last-shot rules

\footnotetext{
${ }^{16}$ See Restatement 2 d of Contracts $§ 39$; CISG art. 19(1).

${ }^{17}$ In a merchant-to-merchant context, a silent party is viewed as accepting an offer only when he made prior affirmative indications that the terms of the offer are desirable, by course of dealings or by soliciting the offer. See Cole-McIntyre-Norfleet Co. v. Holloway, 214 S.W. 817 (Tenn. 1919) (solicitation of offer ); Hobbs v. Massasoit Whip Co., 33 N.E. 495 (Mass. 1893) (course of dealings); James J. White, Autistic Contracts, 45 Wayne L.Rev. 1693, 1702-03 (2000).

${ }^{18}$ There is non-trivial support to the idea that the party whose response to an offer contained non-matching terms, if he did not receive an affirmative acceptance yet proceeded to perform, should be deemed to have agreed to the terms in the offer. See, e.g., Honnold, supra note 2, at 237-238; Valtrol, Inc. v. General Connectors Corp. 884 F. 2d 149, 155 ( $4^{\text {th }}$ Cir. 1989) (discrepant terms in the acceptance are to be ignored). In practice, under one interpretation of 2-207(2), this "first shot" rule applies any time the response includes "different" terms that are not "additional." See White and Summers,
} 
are equally fictitious: in the presence of symmetric non-acceptance, both "break the tie" according to the same methodology, namely, both construe the chronological order of the forms to be crucial. This chronology account, which from the perspective of the parties is mostly irrelevant, can have the adverse effect of inducing the parties to keep sending counter-forms in the hope of firing the last shot. ${ }^{19}$

\section{The "Knockout" Rule}

Modern sales law has increasingly distanced itself for the common law's last-shot tradition. Recognizing that business entities that exchange standard forms rarely read the lawyers' terms on the back of their counterparts' forms (or, if they read, do not regard silence as acceptance of the last shot), the Code sought to eliminate the arbitrariness attached to the last shot rule. Surely, if people do not read and compare the backof-the-form terms, and if the forms are drafted in advance without regard to any particular transaction, the presumption that the first form was "rejected" and "expired" and that the last form was "accepted" is detached from both common sense and commercial reality. ${ }^{20}$ Accordingly, Section 2-207 of the Code sought to restore greater symmetry to a formation process that the common law would otherwise irrationally bias towards the last form. It did so utilizing the so-called "knockout" nule of Section 2-207: material provisions over which the forms disagree are knocked out. ${ }^{21}$ The existence of conflicting terms is taken as mutual rejection, regardless of which was communicated first. As a result of this mutual rejection, the contract contains a gap.

\footnotetext{
supra note 3, at 12-14. This interpretation, however, is re jected by most courts. See Daicom, Inc. v. Pennwalt Corp., 741 F.2d 1569, 1578-79 (10 ${ }^{\text {th }}$ Cir. 1984).

${ }^{19}$ See, e.g., Goldberg, supra note 12, p. 159 ("the parties have an incentive to jockey for position so as theirs is the last shot"); but see Baird and Weisberg, supra note 11, at 1252 (arguing that such prolonged battle of the forms is unlikely.)

${ }^{20}$ See also UNIDROIT Principles of International Commercial Contracts, art. 2.22, cmt 3 (1994) (parties "will normally not even be aware of the conflict between their respective standard terms. There is in such cases no reason to allow the parties subsequently to [...] insist on the application of the terms last sent or referred to.") ${ }^{21}$ This is, of course, an oversimplification of \$2-207's language, which courts and commentators have been laboriously deciphering for the past forty years, but it is consistent with the practice followed by most courts. See White \& Summers, supra note 3, at 10-19. Under amended 2-207, the scope of the knockout result is strengthened. As it drafter, James J. White explained, under the amended provision, there is no precedence by virtue of timing, "the second record has the same power as the first." See White, supra note 4, at
} 
Accordingly, the Code supplements the gaps with its usual statutory gapfiller and, where applicable, with immanent business norms.

The Code's seemingly neutral solution is, however, far from a split-thedifference compromise. Once the parties' conflicting terms drop out, the Code's gap-fillers are often significantly closer to the buyer's form terms than to the seller's. For example, when the buyer's warranty term and the seller's disclaimer of warranty drop out, the Code's gap-fillers include an ever-expanding warranty of merchantability and an express warranty arising from any affirmations of fact the seller may have made orally in the course the parties' communications (which, under the Code's weak version of the parol evidence rule, are often admissible.) The result is therefore quite favorable to the buyer, at times identical to the warranty term the buyer's form included originally. Similarly, when the buyer's remedy terms and the seller's limitations on remedies drop out, the gapfillers are the generous remedies available to the buyer under the Code, including consequential damages.

Parties - and sellers in particular — may try to change this knockout/gapfilling result by drafting a 'mine and mine only' clause, usually stating that the seller is only willing to transact under his terms, and that the buyer's acceptance of the goods would constitute acceptance of the seller's form terms as well. However, when the buyer's form includes non-matching terms, the seller's terms still get knocked-out, along with the 'mine and mine only' clause. ${ }^{22}$ Like the last-shot rule, there is not much either party can do under the Code to escape the effect of the rules governing the battle of the forms. ${ }^{23}$ Unless the seller is willing to prolong the negotiation process in attempt to reach express assent (and thereby also risk a breakdown of the deal), he must live with the terms as chosen by the Code.

\section{The Battle of the Forms under the CISG}

The CISG does not provide an innovative solution to the battle of the forms. Still, it is worth examining the state of the law under the CISG, as it can shed some light on the discussion of the ex-ante effects of the rules. Article 19 of the CISG adopts the mirror-image rule: a reply that

\footnotetext{
${ }^{22}$ See, e.g., Boise Cascade Corp. v. Etsco, 39 UCC Rep. Serv. 410 (Ore. 1984).

${ }^{23}$ But see Farnsworth, Contracts 168 ( $4^{\text {th }}$ Ed. 2004) (a seller can avoid the knockout rule by rejecting the buyer's form and calling his form a "counter-offer".)
} 
adds new or different material terms is a counter-offer, not acceptance. ${ }^{24}$ Article 18(3) of the CISG provides that acceptance may be manifested by conduct, such as payment for, or shipment of the goods. ${ }^{25}$ The combination of the mirror-image rule of Article 19 and acceptance by conduct of Article 18(3) gives rise to the last-shot rule. ${ }^{26}$

In practice, however, battles of the forms in contracts for international sales of goods do not receive a simple uniform treatment. In actual cases, courts refuse to apply the last-shot rule that the convention mandates, and instead apply the knockout rule. This defiance occurs, so it seems, whenever the contract is adjudicated by courts whose domestic law utilizes a version of the knockout rule, such as the U.S. and German courts. ${ }^{27}$ Thus, although the language of the CISG clearly adopts one rule, disputes are adjudicated under a different rule, and reach a result opposite to the one mandated by the statute. For example, when a seller fired the last short with a form disclaiming liability and significantly limiting remedies, a court in Germany nevertheless held that since this conflicted with the buyer's term, the implied warranty of merchantability

\footnotetext{
${ }^{24}$ Art. 19(3) lists terms that are presumed to be material, which include warranty, disclaimer, force majeure, remedies, and arbitration clauses. Thus, most of terms that give rise to battles of the forms are presumed material.

${ }^{25}$ Art. 18(3) provides, in part: "the offeree may indicate assent by performing an act, such as one relating to the dispatch of the goods or payment of the price."

${ }^{26}$ See, e.g., Murray, Chaos II, supra note 1, at 44-45; KRITZER, GUIDE TO THE PRACTICAL APPLICATIONS OF THE UNITED NATIONS CONVENTION OF CONTRACTS FOR THE INTERNATIONAL SALE OF GOODS 184 (1989) C.M. BIANCA \& M.J. BONELL, COMMENTARY ON THE INTERNATIONA SALES LAW: THE 1980 VIENNA SALES CONVENTIONS 179 (1987).

${ }^{27}$ For the doctrinal debate whether courts ought to apply domestic law, see Moccia, supra note 5, at 673-74 (1989) (if the issue is contract validity, art. 4(a) should apply, instructing the court to refer to domestic law.) There are many examples in case law for the rejection of the last-shot rule. For an American case, see Chateau Des Charmes Wines Ltd. v. Sabate USA Inc., 328 F.3d 528 (Ninth Cir. 2003); In Germany, the Supreme Court recently held that "where the CISG applies, [...] according to the (probably) prevailing opinion, partially diverging general terms and conditions become an integral part of the contract (only) so far as they do not contradict each other; the statutory provisions apply to the rest." See VIII ZR 304/00 (English translation in http://www.cisg.law.pace.edu/cisg/wais/db/cases2/020109g1.html); Peter Schlechtriem, Battle of the Forms in International Contract Law (English translation in http://www.cisg.law.pace.edu/cisg/biblio/schlechtriem5.html).
} 
and the statutory remedies apply. ${ }^{28}$ Similarly, a U.S. court facing a battle of the forms contest concerning a forum selection clause applied the 2207 knock-out rule while recognizing that the case is governed by the CISG, conveniently stating that the CISG would reach the "same conclusion" as the Code. ${ }^{29}$ The resistance in U.S. courts to the CISG's mirror image methodology is quite prevalent. ${ }^{30}$ Generally, and consistent with this loyalty-to-domestic-rules observation, courts rarely cite CISG decisions from other countries. ${ }^{31}$

This uncertainty concerning the prevailing rule can be seen as highly problematic. If parties cannot ascertain upfront which rule will be applied to a potential battle of the forms, they also cannot predict which form or which terms would apply. Don't parties have to know these matters in order to correctly adjust the dickered terms, specifically the price? Wouldn't a seller need to know which warranty term applies to the transaction when pricing the goods? Under the CISG, even if the seller fired a last shot that included warranty disclaimers, he might end up liable under an implied warranty of merchantability, pasted into the transaction as a gap-filler by an American court applying the knockout rule.

\section{The "Reasonable Shot" Rule}

\section{The Rule}

Arbitrators are well familiar with the procedure of final offer arbitration (FOA), which works in the following way. Consider baseball's salary arbitration, where FOA has been widely and successfully used. When a player is committed to play for a specific team but the player and the team are unable to agree on a salary, each party submits a proposal to the arbitrator, who must then choose one of the two proposals - the one that is closer to what she considers as the most appropriate salary. The arbitrator cannot come up with a third, in-between figure. She may hear arguments by the parties why one proposal is more reasonable than

\footnotetext{
${ }^{28}$ VIII ZR 304/00, id.; Larry DiMatteo et al., The Interpretive Turn in the International Sales Law: An Analysis of Fifteen Years fo CISG Jurisprudence, 24 Nw. J. Int'1 L. \& Bus. 299, 352-53 (2004).

${ }^{29}$ Primewood, Inc. v. Roxan GMBH, WL 1777501 (D.N.D.)

${ }^{30}$ For example, in Claudia v. Olivieri Footwear, WL 164824 (S.D.N.Y.), the court resisted the application of CISG art. 8(3) rule that acceptance of delivery, without further communication, manifests acceptance of the terms in the last shot.

${ }^{31}$ DiMatteo et al, supra note 28, at 357.
} 
another, but must eventually pick one of the two. ${ }^{32}$ Her decision on how much a player ought to be "valued" is based on comparing the player to other players, according to the various performance statistics and factors specified in the collective bargaining agreement.

The battle of the form can be approached in a similar fashion. In line with a proposal first made by Victor Goldberg, ${ }^{33}$ under the reasonableshot rule the court's role would be to select the form that contains the more reasonable terms. ${ }^{34}$ Like FOA, the court must choose only between the parties' forms, and cannot devise any "third" option. This is in contrast to the knockout rule, where the court can import provisions not found in either form. It differs from the first shot and the last shot rules since the court has to choose not according to the chronological order of forms, but instead in the order of their reasonableness. The court chooses the lesser of two "evils", not the latter of the two.

The determination which form is more reasonable can be broken down into the different matters that the forms regulate-warranties, remedies, forum selection, etc. - - with the more reasonable term coming not always from the same form. Under such issue-by-issue procedure, the reasonable shot is not necessarily one party's integral form, but might be an assembly of different fragments from the overall totality of the terms both parties drafted. As contrasted with the "package" approach, that restricts the court to choose one of the forms in its entirety, the issue-byissue format reduces the risk that parties face and increases the ability of the court to tailor a most reasonable set of provisions. ${ }^{35}$ And as will be argued below, it further sharpens the incentives to draft terms in a

\footnotetext{
${ }^{32}$ For studies of baseball's FOA, see sources cited in note 13, supra.

${ }^{33}$ See Goldberg, supra note 12, at 166.

${ }^{34}$ The reasonable-shot rule proposed here is somewhat different than the best-shot rule proposed by Goldberg, id. Goldberg's version requires courts to pick the fairer of the two forms, whereas the analyzed here requires courts to pick the more reasonable of the two forms. While Goldberg, throughout his article, also refers to the form that is "more reasonable," his criterion differs in that it focuses on the fairness of the terms and proposes the approach of the "Golden Rule" to determine comparative fairness. The analysis here, in contrast, focuses on the efficiency of the terms and offers different criteria to determine comparative efficiency. See text accompanying notes 38-43, infra.. 35 See Elissa Meth, Final Offer Arbitration: A Model for Dispute Resolution in Domestic and International Disputes, 10 Am. Rev. Int'l Arb. 383, 394 (1999).
} 
reasonably moderate fashion, because it would be impossible to "sneak" an unreasonable term into an otherwise reasonable package. ${ }^{36}$

\section{2. "More Reasonable Terms"}

Can a court determine which party's terms are more reasonable? Finaloffer arbitration has been successful in resolving disputes over salaries, where each party submits a numeric figure and where market comparisons exist to determine which figure is more reasonable. ${ }^{37}$ Can the same technique succeed in resolving disputes over terms that are not easily quantifiable, and where exact parameters are not available?

At times, one party's terms may be so unreasonable that courts would find it easy to choose the other party's form. In fact, they already conduct such scrutiny under other doctrines, so no new adjudicatory skill would be required. ${ }^{38}$ Thus, for example, if each party states a different arbitration provision, one requiring to arbitrate at a remote location or in any fashion that imposes a significant cost and the other picking a natural and accessible arbitration forum, it is easy to compare and determine that the latter is more reasonable. Or, if each party drafts a different remedy provision, one a reasonable estimate of the loss and the other includes a limitation that undermines the purpose of remedies, again it is standard practice for courts to strike down the one that is less reasonable.

\footnotetext{
${ }^{36}$ Goldberg argues that an all-or-nothing approach, looking at each form in its entirety, is essential for assessing the overall fairness of the package. See supra note 12, at 166. Arbitrators, however, see merit in the issue-by-issue procedure. See Robert Howlett, Interest Arbitration in the Public Sector, 60 Chi.-Kent L. Rev. 815, 831 -33 (1984).

37 Even in baseball arbitration - the most successful implementation of FOA - it is not clear how to determine the salary the player merits. While there are many useful players' statistics, comparison requires subtle judgment on part of arbitrators, e.g., how senior can the comparable group of players be, how to value non-wage or contingent wage provisions, which of the many categories of production to use, etc. See Abrams, supra note 13, 157-164. The FOA technique has also been proposed in many other areas of dispute that pose difficulties of determining what is the most reasonable term. See, e.g., Meth, supra 35 (applying FOA to disputes over contract damages); Christian Henrich, Game Theory and Gonslaves: A Recommendation for Reforming Stockholder Appraisal Actions, 56 Business Lawyer 697 (2001) (arguing that FOA can apply to disputes over share value in freeze -outs.)

38 For courts' scrutiny of the reasonableness of limitations on remedies, see, e.g., UCC $2-719 \mathrm{cmt} 1$ ("reasonable agreements limiting or modifying remedies are to be given effect”); Murray v. Holiday Rambler, Inc., 265 N.W.2d 513 (Wisc. 1978). For courts' scrutiny of reasonableness of forum clauses, see, M/S Bremen v. Zapata Off-Shore Co., 407 U.S. 1 (forum selection clause is enforceable unless it is " "unreasonable' under the circumstances”); see also Brower v. Gateway 2000, 246 A.D. 2d 246 (NY 1998).
} 
Often, a particular term in one party's form-say, a term governing the procedure for modification-has been followed in prior dealings between the parties, elevating its stature to be part of the "agreement,"39 thus rendering it reasonable. In fact, courts already take such factors into account when determining whether an additional term on the counterform exhibits a material difference. ${ }^{40}$ For example, when a limitation of remedy clause is deemed reasonable, it is considered immaterial under 2207(2). ${ }^{41}$ So here too, the inquiry necessary to determine the reasonableness of a term is one that courts are accustomed to make.

From an efficiency perspective, a term is more or less reasonable depending on whether it increases the overall value of the transaction or merely shifts value in zero-sum, or negative-sum fashion to its drafter. A provision that requires a seller to warrant goods is more reasonable when the seller is the most effective monitor of the quality of the goods or if he is the least cost avoider or repairer of defects. The same provision is less reasonable when it is the buyer who can best protect the asset against malfunctions, or who has superior information about nonconformities. ${ }^{42}$ Or, a provision that entitles a negligent party to indemnification is unreasonable when it undermines the incentives to take care. ${ }^{43}$ Generally, terms that serve a productive cost-saving purpose, as opposed to merely rent-extraction, are presumptively reasonable.

Additionally, the reasonableness of a term depends on whether or not the cost saving that it brings its drafter was shared, ex ante, with the other party. When a seller disclaims warranties or limits the buyer's remedies, the term is nevertheless reasonable when the saving from it was shared, through a lower price, with the buyer. For example, if a seller disclaims

\footnotetext{
39 "Agreement" is defined by the Code to include all past practices. See UCC 1-201(3).

${ }^{40}$ See, e.g., GuIDE TO PRACTICAL APPLICATION OF THE CISG 172 (1993).

${ }^{41}$ UCC 2-207 cmt. 5 (examples of terms that incorporated in the contract unless objected to include clauses "limiting remedies in a reasonable way"); See also Hydraform Prods. Corp. v. American Steel \& Alum. Corp., 498 A. 2d 339, 343 (N.H. 1985).

${ }^{42}$ See Baird \& Weisberg, supra note 11, at 1250.

${ }^{43}$ A similar inquiry is often conducted under UCC 2-207 (2)(b) to determine whether terms in the response constitute a material change. The main criterion in this inquiry is the "hardship" imposed by the terms in the response. Thus, for example, courts have held that sweeping indemnity clauses impose undue hardship. See Maxon Corp. v. Tyler Pipe Indus., Inc., 497 N.E.2d 570 (Ind. 1986).
} 
any liability for goods lost in the course of shipment, this term is more or less reasonable depending on whether the buyer was offered the opportunity to purchase a more expansive liability coverage but opted for the cost-saving alternative. Similar to the law of unconscionability, even an extremely pro-seller term can be reasonable if the buyer chose it out of a menu of options.

Recall that under the Code's gap-filling methodology, courts are asked to perform an even more exacting task, of picking the reasonable terms on their own. The Code's gap-fillers are sometimes not much more than standards of reasonableness, requiring courts to figure out "reasonable duration" of warranties, "fair average quality," etc. If we believe that courts can potentially draft terms that are reasonable, wouldn't they also be able to tell which of the contesting terms is more reasonable? Moreover, the issue-by-issue format is a way in which the determination of the more reasonable form can be broken down rather than made in a 0-1 fashion. In situations in which it is difficult to determine which form is more reasonable, the court can balance the number of issued decided in favor of each party.

\section{Examples}

Duration of Warranty. In Northrop Corp. v. Litronic Industries, ${ }^{44}$ the forms of the parties disagreed over the duration of the warranty for electronic boards. The seller's form contained a 3-month warranty term; the buyer's form contained a warranty with no time limit. The buyer first inspected the goods after six months, and upon discovering defects rejected the goods and sought remedies. The court knocked out the discrepant warranty terms and filled the gap with a warranty for "reasonable" time. ${ }^{45}$ The court did not have to designate a specific duration as the most reasonable; it merely decided that the six months it took the buyer to invoke the warranty was reasonable. The buyer won.

Under the reasonable-shot rule, the court would have likely reached a different resolution, in favor of the seller. The court would not need to designate an intermediate duration, nor to evaluate whether six months was reasonable. It would only have to determine which of the two terms, three months or unlimited duration, is more reasonable. However long is

\footnotetext{
4429 F. 3d 1173 ( $7^{\text {th }}$ Cir. 1994)

45 The trial court relied on UCC \$2-309 which allows buyer to reject non-conforming goods within a reasonable time.
} 
the reasonable period for a buyer to test the goods, it must be closer to three months than to the unlimited duration the buyer allotted itself. For goods that are assembled into a larger system and sold downstream to users that the seller cannot monitor, it would unreasonable to require the seller to provide free lifetime warranty (or even the 4-year duration permitted under the statute of limitation, §2-725). If the boards can first be inspected for defects, a reasonable warranty would cover only the inspection period. ${ }^{46} \mathrm{~A}$ three months period for inspection, while stingy, is not unmanageable and thus not unreasonable.

Note, interestingly, that in a dispute like this, the buyer would lose even if he attempted the rejection one day past the three-month term. Under the current regime, it would suffice for the buyer to show his inspection occurred within a reasonable time and, surely, one more day does render the rejection period unreasonably long. Under the reasonable-shot rule, in contrast, the buyer would not be able to argue that his actual timing is reasonable; he would have to show that his contractual term-unlimited duration-is more reasonable. Even if his actual conduct is reasonable, a party to such a dispute would be unable to overcome the unreasonableness of its contractual boilerplate term.

Disclaimer of Warranty. A very common battle of the forms occurs between a seller who disclaims all implied and express warranties and a buyer who either is silent or includes a warranty of merchantability clause similar to UCC 2-314. For example, in Roto-Lith v. Bartlett, ${ }^{47}$ seller sold glue to be used by the buyer to seal spinach bags. The glue failed. Was the seller's disclaimer reasonable? Of course, the answer depends on various case-specific factors such as the seller's knowledge of the buyer's needs, the ability of the buyer to test the glue or to anticipate difficulties in using it, how the glue was used, etc'. The point here is not that one party's term is universally more reasonable; rather, the point is that reasonableness can be ascertained by looking at factors that are verifiable at trial. In that case, commentators perceive the disclaimer by this seller as reasonable. ${ }^{48}$ Notably, in writing on this case, Grant Gilmore opined that "it would have been outrageous to have

\footnotetext{
46 See UCC 2-607(3).

47297 F.2d 497 ( $1^{\text {st }}$ Cir. 1962).

48 See Baird and Weisberg, supra note 11, at 1250-51, for analysis of the Roto-Lith case and the factors that suggest that a disclaimer of warranty is reasonable.
} 
saddled the seller with warranties which (as the buyer knew) he had expressly (and quite reasonably) disclaimed."(Emphasis added) $)^{49}$

Arbitration. What about the other common battle of the forms, where one party's form (usually the seller's) includes an arbitration term and the other party is either silent on forum selection or includes a different arbitration term? Arbitration has many advantages that normally make it a reasonable, cost-saving choice. But it is also occasionally designed to prevent buyers from obtaining a practical remedy. When, say, a filing fee is unreasonable given the stakes, or when the arbitration forum is geographically inaccessible, or when either the procedure or the substantive rules of the arbitration forum exclude a reasonable remedy, courts can-and already often do-strike down the arbitration clause as unreasonable. $^{50}$ To show that the arbitration clause is unreasonable, a party can identify an existing alternative that is more accessible and reasonable. In the same way that negligence in torts can be demonstrated by focusing on untaken precautions, unreasonableness in contract drafting can be shown by reference to un-drafted alternatives.

Consequential Damages. Finally, consider a battle between the seller's term which limits damages for defective goods to not exceed the contract price versus the buyer's term which expands damages to include all consequential losses. Neither of these terms is first-best. The seller's term, by excluding all expectation losses, sets damages too low; the buyer's term, by including unforeseeable and unpreventable components of the loss, sets damages too high. Courts cannot realistically conduct a direct comparison of social welfare under these two terms. However, the buyer's term may be deemed reasonable if some of the idiosyncratic facts that affect his losses were communicated to the seller explicitly. An unread boilerplate term in the buyer's form is not adequate communication; an oral statement concerning the buyer's needs is. Thus, the buyer would lose because he did not choose the reasonable medium to alert the seller to his special circumstances and thus did not give the seller an opportunity to price the added liability.

\footnotetext{
${ }^{49}$ Letter of Grant Gilmore to Robert Summers, cited in White, supra note 4, at _-.

${ }^{50}$ See Brower v. Gateway 2000, 247 A.2d 247, 255 (NY 1998); Matter of Teleserve Sys. [MCI Telecommunications Corp.], 230 A.D.2d 585, 594 (NY 1997).
} 


\section{ANALYSIS OF EX-ANTE EFFECTS}

\section{A. Incentives to Read}

The first type of incentive that may be affected by the rules governing the battle of the forms is the incentive to read the fine print in the other party's form. Of course, reading terms in standard form contracts is costly. It is plausible, in fact quite likely, that the social value of such increased incentive does not justify the cost. But even without conducting any cost-benefit analysis of the incentive to read, ${ }^{51}$ it is not clear if there can be much variance across the different rules with respect to the incentives to read.

Consider first the last-short rule. Here is a plausible conjecture: under the last-shot rule, parties would have a more powerful incentive to read the terms prior to performance. ${ }^{52}$ If, say, the seller fired the last shot, the buyer-realizing that the seller may try to sneak in terms unfavorable to buyer-would have the incentive to read the terms in the seller's invoice before silently accepting them, to verify that he is willing to proceed under the seller's terms. He might decide, after reading, that he is better off taking his business elsewhere, or perhaps insisting on some offsetting concessions from the seller. ${ }^{53}$ In contrast, under the knockout rule, neither party would have such an incentive to read. Under this rule, each party expects that even if the other party drafted selfish terms, they will drop out and would not be part of the contract. Thus, there is no gain to reading and raising havoc upfront.

It is far from clear that the last-shot rule would indeed provide the added incentive to read. The actual ritual of contracting - of exchanging forms

\footnotetext{
${ }^{51}$ For such analyses in a consumer context, see Avery Katz, Your Terms or Mine: The Duty to Read Fine Print in Standard Form Contracts, 21 Rand J. Econ 518 (1990); Clayton Gillette, Rolling Contracts as an Agency Problem, 2004 Wisc. L.Rev. (forthcoming).

52 See, e.g., Ostas and Leete, supra note 6, at 378 (1995) (last shot rule "provides an incentive for business actors to carefully read and discuss al the contract terms"); Baird and Weisberg, supra note 11, at 1257 ("the seller knows that at least some buyers will be careful enough to read the seller's form.")

53 The premise that at least some buyers have the incentive to read underlies the economic analysis of consumer standard form contracts. See, e.g., Schwartz \& Wilde, Intervening in Markets on the Basis of Imperfect Information: A Legal and Economic Analysis, 127 U. Pa. L.Rev. 630, 638 (1979); Kornhauser, Unconscionability in Standard Forms, 64 Calif. L. Rev. 1151 (1976).
} 
and accepting shipment-is conducted by "underlings" of seller and buyer who sit in their offices with a telephone and a stack of form contracts drafted by their lawyers. ${ }^{54}$ In large firms doing hundreds of transactions, these contracting agents do not have the institutional training nor the authority to read and dicker with the lawyers' terms, and they rarely have the capacity to trade away a particular boilerplate term for a more favorable price. ${ }^{55}$ In fact, they often don't even read or remember their own boilerplate terms. ${ }^{56}$ Are these the agents who are going to read their counterparts' fine print terms? Even if an innovative organization were to authorize its sales agents to read and negotiate the warranty and arbitration terms, these agents would likely be dealing with counterpart agents who are only authorized to deal on a take-it-or-leaveit basis. In any event, reading is futile. ${ }^{57}$

One may nevertheless wonder whether a change in the legal regime, say from the knockout rule to the last-shot rule, or perhaps to the reasonableshot rule, would bring about a change in contracting practices and would challenge more organizations to train their sales and purchasing agents to read, process, and adjust boilerplate terms. Aside from the wellrehearsed observations concerning the economic value of unread contracts in a mass-transaction economy, there is little reason to expect that such an effect could take place. For one, there are existing jurisdictions that have long applied a last-shot regime and yet do not exhibit a more prevalent practice of reading printed terms. ${ }^{58}$ And if parties don't read the last shot under the last-shot rule, there is even less reason to expect that they would do so under any other rule, particularly the reasonable-shot rule. Apathy to each other's boilerplate terms is not a

\footnotetext{
${ }^{54}$ White \& Summers, supra note 3, at 6-7.

55 See, generally, Stuart Macaulay, Non-Contractual Relations in Business: A Preliminary Study, 28 Amer. Soc. Rev. 55 (1963); Murray, Chaos I, supra note 1, at 1317, 1373; Gregory Travalio, Clearing the Air after the Battle: Reconciling Fairness and Efficiency in a Formal Approach to UCC 2-207, 33 Case W. Res. L. Rev. 327, 330 (1983).

${ }^{56}$ See Macaulay, id., at 59.

57 See Daniel Keating, Exploring the Battle of the Forms in Action, 98 Mich. L.Rev. 2678, 2699-2700 (2000) (reporting survey results that confirms that parties rarely read the form terms prior to the transaction.)

${ }^{58}$ See, e.g., Report of the Secretary-General: Formation and Validity of Contracts for the International Sale of Goods, 10 U.N. Commission on International Trade Law 29, U.N. Doc. A/CN.9/128 (1977) ("the employees of both parties will rarely, if ever, read and compare the printed terms. All that is of importance to them are the terms which have been filled in on the forms")
} 
result of a calculated conclusion that those term matter more or less depending on the legal regime. Rather, it is a manifestation of the attitude that it is not the fine print that matters, but the bargain in fact between the parties.

This conclusion - that agents are not sensitive at all to the legal rules governing the battle of the forms-is reinforced by the experience with the battle of the forms under the CISG. As noted above, while the CISG clearly designates the last-shot rule, in practice courts often apply the knockout rule. There is no indication, however, that any of this ambiguity concerning the law affects in any way the contracting practices of the parties. It might be puzzling, how do parties enter contracts for sales of international goods without the ability to predict which rule would govern the battle of the forms and which terms would prevail. Isn't the battle of the forms rule as important to the parties as it is to legal scholars and reformers? Apparently, this rule-and the fate of the boilerplate terms that the parties exchange-does not seem essential to the businessmen and their agents who negotiate the dickered terms. At the time of exchange of communications and performance of the contract, the divergence in boilerplate terms is often neither addressed nor recognized, and the agents behave as if they are not concerned with the potential dispute resolution rules or remedies. Those who are part to the deal are interested in assent over the performance terms. For these agents, the fate of the terms in fine print is, at the time of contracting, insignificant.

Accordingly, if the rules governing the battle of the form can have any incentive effects, they must be aimed at the lawyers of both parties, operating in the background in drafting the forms. These are the parties who indirectly "negotiate" the boilerplate terms, who care about their contingent application, and who can anticipate the impact of the battle of the forms rules on the enforceability of these terms. Indeed, hornbooks are replete with suggestions for practitioners on how to draft their contracts given the different consequences that courts might attach to various drafting techniques. ${ }^{59}$ That is, lawyers who draft the fine print are the "true" rivals in the battle of the forms. A successful solution to the battle of the forms would give these role players an incentive to reach mutual assent — to design forms and boilerplate terms that agree.

\footnotetext{
${ }^{59}$ See White \& Summers, supra note 3, at 31.
} 


\section{B. Incentives to Draft}

\section{The Last-Shot Rule versus the Knockout Rule}

The battle of the forms is the result of a reality in which many of the "legal" aspects of a deal are not affirmatively negotiated. Because the principals negotiating the deal are interested only in the performance terms, and because the organizational structure of each party usually requires it to utilize forms to memorialize the terms of the deal, there is an opportunity for both sides to insert one-sided terms which would likely escape the other party's scrutiny and would, with some likelihood, secure a benefit. In fact, not only is there an opportunity to use one-sided form terms, there is a clear incentive to do so. The risk that these boilerplate terms will be detected and influence the other party's willingness to deal is usually minor.

How do existing solutions to the battle of the forms fair with respect to the incentives to draft? Here is another conjecture: under the last-shot rule, parties would have a more powerful incentive to draft reasonable terms. ${ }^{60}$ At the drafting stage, each party would recognize that the more one-sided its form, the more likely is the other party to reject it and respond with a counter offer. Thus, to reduce the chance of rejection, an offeror would want to draft more moderate terms, to the mutual interest of both parties. ${ }^{61}$

It is unlikely, however, that this "moderation" conjecture is robust. ${ }^{62}$ For one, it is based on the premise that a recipient reads the terms of the offer and decides, ad-hoc, after evaluating the substance of these terms, whether or not to respond with its own counter-offer. But, as argued above, parties rarely read the boilerplate terms in the forms, not even their own. The practice of sending a counter-form-a purchase order, invoice, and acknowledgment - is a matter of standard business practice,

\footnotetext{
${ }^{60}$ See, Baird and Weisberg, supra note 11, at 1252-57 ("under the mirror-image rule, each party has an incentive to hypothesize the terms that the parties would have settled upon had they dickered over them.")

${ }^{61}$ Some have argued that even if terms are read only by a fraction of transactors, there is enough incentive for drafters to draft more balanced terms. See, e.g., Schwartz \& Wilde, supra note 53, at 638; but see, Gillette, supra note 51, section II.B, for analysis of some weaknesses in this argument.

${ }^{62}$ For another skeptical account, see Goldberg, supra note 12, at 164-5.
} 
which Judge Posner called "a thoughtless use of boilerplate form." Recall: the fundamental business logic of using standard forms is to save the transaction cost of customized terms and of complex precontractual adjustments. It is the same business logic that suggests that even if one were to moderate its own terms, this would not affect the terms in the response. And without such benefit, the strategy of moderation is not likely to be employed. The overwhelming incentive under the last-shot rule is to draft self-interested forms and to try and sneak them in as late as possible prior to performance. Indeed, parties often perform the transaction while continuing to send forms back and forth, making it further difficult to ascertain who fired the last shot.

Similarly, under the Code's knockout rule, parties do not have any incentive to moderate their standard form term. From the buyer's perspective, the knock out result is quite desirable, as it opens the door to the Code's pro-buyer gap-fillers such as warranties, consequential damages, a limited list of sellers' excuses, and no arbitration. For the buyer, then, the risk of engaging in a battle of the forms is not much of a deterrent: he is often equally happy to be governed by the Code's gapfillers as by his own form provisions. He has no incentive draft terms in a way that might avoid a battle of the forms. For the seller, in contrast, the battle of the forms is more costly. To avoid the dilemma of either accepting the buyer's form or knocking it out and importing the Code's gap fillers, the seller might try to induce the buyer to accept the seller's terms, perhaps by drafting a less one-sided form, more acceptable to the buyer. But as long as the buyer has nothing to lose by using its own form, there is no reason for the seller to expect that any restraint on his part would prevent a battle of the forms, and thus no clear reason to draft moderate provisions. As White \& Summers soberly conclude, if a seller wants to limit liability and cannot get the buyer to agree, all he can do "ex-ante," after having an extra martini every night, is to shrink the capitalization of the firm. ${ }^{64}$

In sum, the reason that the battle of the forms remains an acute problem under both the last-shot and the knockout rules, and that parties regularly continue to draft forms in a self-serving manner, is that these regimes do not provide any incentive for the parties to draft reasonable terms. When the lawyers draft the boilerplate provisions, either generally to fit all

\footnotetext{
${ }^{63}$ Northrop Corp. v. Litronic Indus., 29 F.3d 1173, 1179 (7 $7^{\text {th }}$ Cir. 1994).

${ }^{64}$ White \& Summers, supra note 3, at 31.
} 
transactions or specifically tailored to a particular deal, they have no motivation to draft terms that are mutually beneficial. Rather, the intraorganizational pressure is to think one-sidedly. ${ }^{65}$ Occasionally, when these selfish terms are exposed and turn out to be deal breakers in the bargaining, special accommodations can be made. But in the majority of situations, the terms are only discovered ex post facto, at which point they can only benefit their drafter.

\section{The Reasonable-Shot Rule}

The reasonable-shot regime attaches a substantial cost to the strategy of drafting unreasonably self-serving forms, and it potentially provides incentives for the parties' forms to converge. ${ }^{66}$ When parties expect the court to enforce their terms only if they are more reasonable than the terms of their counterparts, there is a powerful incentive to draft these terms in a reasonable, less one-sided manner. This is independent of whether a party expects its form to be accepted by the other party, or even to be read by the other party. The reason a party would be induced to draft terms that are more balanced and reasonable is not the expectation to be rewarded for it in the negotiation stage, nor the expectation that it would translate into higher willingness to pay by the other party. It is the expectation that the more reasonable the form, the more likely are its terms to be enforced, ex-post. The incentive this rule gives is founded on the recognition that the true battle-of-the-forms interaction is between the drafters of both forms, the two "legal departments" that don't necessarily negotiate with each other. Each drafter would be induced to change its drafting strategy because of the fear that its counterpart would do the same and come out with the upper hand, in the contest over which form more reasonable. ${ }^{67}$

Eventually, it can be imagined that the dynamics under this rule are such that a race to the middle would take place. ${ }^{68}$ Even if each party only

\footnotetext{
${ }^{65}$ See Avery Katz, On the Use of Practitioner Surveys in Commercial Law Research, 98 Mich. L.Rev. 2760, 2769-70 (2000) (discussing intra-firm tensions between lawyers and sales agents that might explain the one-sided drafting of the forms.)

${ }^{66}$ See Goldberg, supra note 12, at 166 (the "best-shot" rule gives each side an incentive to move towards the center.)

${ }^{67}$ In an interview, some in-house counsel noted that best-shot rule might cause contract drafters to rethink their current drafting strategies. See Keating, supra note 57, at 2711.

${ }^{68}$ The race to the middle under a FOA procedure is well recognized. See, e.g., Stern et al., FINAL OFFER ARBITRATION: THE EFFECTS OF PUBLIC SAFETY EMPLOYEE
} 
wants to draft terms that are incrementally more reasonable than the other party's terms, it also realizes that the other party would try to do the same. It is a familiar equilibrium in contests that have these dynamics for both parties to align themselves in the middle. ${ }^{69}$ In the present context, the more predictable the court's view of what constitute reasonable terms, the closer the parties' terms would be to it, and the practice of drafting biased terms would cease. And if the courts' position on reasonableness is known with certainty, the equilibrium involves both parties drafting identical forms, representing a reasonable majoritarian compromise. The solution to the battle of the forms could have the paradoxical effect of eliminating the battle of the forms from arising in the first place. At the very least, it brings the parties forms closer together, with each party being less satisfied with its own form but more satisfied with the opponent's form. ${ }^{70}$

The "race to the middle" described above depends, of course, on whether parties can anticipate what courts would view as a reasonable "middle." In salary arbitration, this convergence may fail when parties are uncertain about the arbitrator's preferred settlement. ${ }^{71}$ The greater the uncertainty, the weaker the incentive to submit a more reasonable position. Still, even in these circumstances, where the rule does not guarantee convergence, it provides more powerful incentives for moderation than other rules. The reason is simple: under this rule, a party's decision to draft a concession, however costly it is when the concession is adopted into the contract relative to a contract without such a concession, is at least partially offset by the new benefit, in terms of the greater chance of winning the battle of the forms. When this endogenous benefit is accounted for, even significant concessions have only minor impact on this party's expected profit. ${ }^{72}$

BARGAINING 144 (1975) (providing empirical evidence that FOA moderates the submissions of opposing parties);

${ }^{69}$ ROBERT GiBBONS, GAME THEORY FOR APPLIED ECONOMICS 23-26 (1992) (when parties have perfect information, their positions converge).

${ }^{70}$ For example, when a dispute between the IRS and Apple Computers over tax debt exceeding \$100 million was resolved by FOA, both parties declared themselves winners. See After Successful Use of Baseball Arbitration, Apple, IRS Both Declare Themselves Winners, 11 Alternatives to High Cost Litigation 163 (1993).

${ }^{71}$ See Steven J. Brams, NEGOTIATION GAMES: APPLYING GAME THEORY TO BARGAINING AND ARBITRATION 71-75 (1990)

72 See Jay Coleman et al, Covergence or Divergence in Final-Offer Arbitraion in Professional Baseball, 31 Industrial Relations 238, 244 (1993). 
Nevertheless, the more predictable the reasonableness standard, the more likely are parties to race to the middle. If there is a broad spectrum of what parties' perceive as reasonable (or, what they believe courts would view as reasonable), the parties would be relatively safer in drafting terms at conflicting ends of this spectrum. As the spectrum narrows, the reasonable shot rule would generate more powerful incentives for the parties' forms to converge. Thus, the critical factor for this rule to succeed is the ability to predict the court's position. This, of course, depends on whether courts' determination of what constitute reasonable terms is principled and informed. If comparative efficiency is the yardstick utilized to determine reasonableness, I highlighted above several factors that should be looked at, and argued that courts are in fact already familiar with the relevant inquiries.

Of course, for the reasonable shot rule to generate predictable outcomes, it is not enough that courts follow a well-defined methodology in comparing the parties' forms, they must also have the information and institutional capacity to conduct accurate comparisons. Given the existing experience, it is probably easy to come up with examples for battles of forms in which it is impossible to determine comparable reasonableness. On the basis of these examples, it would be tempting to conclude that courts do not have the information necessary to compare reasonableness and that the rule would lead to indeterminacy, rather than to convergence. However, we should keep in mind that the difficulty in determining reasonableness is endogenous to the legal regime. Under the reasonable shot rule, parties would have a greater incentive submit evidence to show that their terms are more reasonable. In the same way that baseball's FOA introduced new ways of measuring players' contribution to their teams' success, such that did not exist before the procedure was launched (and recall: baseball already had many statistical ways of measuring productivity), ${ }^{73}$ the rule can induce parties to provide information that would help measure the reasonableness of terms. ${ }^{74}$ For

\footnotetext{
73 In baseball arbitration, FOA “focuses the parties' presentations [so that] each side must explain to the tribunal why the player is worth more or less than the midpoint. [Experts] have devised complex formulae [...] to describe a player's contribution to his club's success." See Abrams, supra note 13, at 156-7.

${ }^{74}$ In the context of appraisal of minority share value in freeze-outs, Chancellor Allen of Delaware discussed the merits of FOA in improving the quality of information available to courts. See Cede \& Co. v. Technicolor, Inc., No. CIV.A.7129, 1990 Del. Ch. LEXIS 259 (Del. Ch. Oct. 19, 1990); Henrich, supra note 37, at 701, 715.
} 
example, courts might learn that a particular provision is reasonable in light of intra-firm concerns, information currently deemed irrelevant.

Further, even if there would be some initial uncertainty as to what courts regard more reasonable terms, over time a body of jurisprudence and precedents would accumulate and make subsequent adjudication easier and more predictable. ${ }^{75}$ Since parties on the same side of the transaction divide use similar terms, the different types of substantive battles that arise is limited. This is particularly true in e-commerce. ${ }^{76}$ Whether it is a battle between warranties versus disclaimers, limitations versus consequential remedies, arbitration, or any other common frontier, the patterns of dispute are fairly limited and, as happened in baseball arbitration, the parties can learn to anticipate courts' decisions. ${ }^{77}$

Thus, the incentive to draft reasonable terms under the reasonable-shot rule could emerge gradually. Initially, when there is still much uncertainty among transactors as to what terms are more or less reasonable, this regime will not generate convergence. But over time, as the information courts acquire improves and as accumulating case law identifies categories of unreasonable terms, parties would learn not to draft certain one-sided terms. These dynamics would potentially persist as long as the criteria for reasonableness are coherent and are capable of yielding deterministic outcomes.

\section{CONCLUDing R EMARK}

\footnotetext{
${ }^{75}$ See Baird \& Weisberg, supra note 11, at 1246 (arguing that disputes over the meaning of "material," while frequent in the early years of the Code, would decrease as the likely outcome of litigation becomes predictable).

${ }^{76}$ Under increasingly prevalent technologies, contract terms are standardized and electronically tagged, often exchanged between computers. See, e.g., Margaret Jane Radin, Humans, Computers, and Binding Commitment, 75 Ind. L.J. 1125, 1130 (2000).

${ }^{77}$ In baseball arbitration, when FOA was initially invoked, arbitrators did not have a clear reference on how wages should correspond to statistical measures of performance and how to relatively weigh the different factors. For example, arbitrators had a difficulty applying factors that are more subjective, such as the player' crowd appeal or spontaneity. It is only over time, with the accumulation of precedents and comparable cases, that the formula for reasonable wage became more obvious and that a quantitative yardstick became known. See Abrams, supra note 13, at 165.
} 
Even if the analysis in this paper is correct and the reasonable-shot rule provides superior incentives to draft efficient boilerplate forms, there remains a conceptual problem that the paper did not address. Recall that for the reasonable shot rule to succeed, courts must be able to determine which terms are more reasonable. But if courts are capable of doing so, why not simply have the courts substitute the parties' forms with what they deem as most reasonable? Why not endorse a regime in which the most reasonable terms govern, dictated by court regardless of whether one party happened to draft a form that reflects them? That is, instead of reaching this outcome indirectly, implementing it gradually through an incentive scheme that requires parties to guess the courts' position, courts can regulate it directly and immediately (and allow parties to opt out of it only through consented form.)

This question implicates a more fundamental observation concerning the Code's gap-filling methodology. In a sense, under the existing knockout rule courts already do as suggested, substitute the parties non-matching terms with the perceived most reasonable gap-fillers. The problem, as I argued in the paper, is that these gap-fillers are not quite so reasonable. Being so rigidly favorable to buyers, the Code's gap-fillers do not mimic a hypothetical bargain - they do not represent what parties who want to maximize their surplus would rationally agree upon. The problem, then, is not with the battle-of-the-forms rule that knocks out both parties' terms, but with the content of the gap-fillers that take their place.

Still, even if the Code's gap-fillers were more efficient and better tailored to substitute the parties' conflicting terms, the reasonable-shot regime could be advantageous. For one, it places a less exacting burden on courts: picking the more reasonable term is easier than drafting the most reasonable one from scratch, especially so when one party's term is distinctly unreasonable. Moreover, the reasonable-shot rule strengthens contract as an institution privately regulated by the parties, rather than publicly dictated by the court. Even if the term governing the transaction is the same as it would be under the gap-filling regime, under the reasonable shot rule the enforced term is privately tailored. Finally, and perhaps most importantly, the reasonable shot rule encourages parties to help courts in identifying the reasonable terms. By drafting terms into their standard forms and by arguing ex-post why their terms ought to be enforced, parties provide courts with a stronger factual basis for the determination, potentially improving its accuracy. 